\title{
PITFALLS OF TRADITIONAL TECHNIQUES WHEN STUDYING DECOMPOSITION OF VASCULAR PLANT REMAINS IN AQUATIC HABITATS
}

\author{
F. Bärlocher \\ Dept. of Biology, Mount Allison University, Sackville, N.B., E4L 1G7. Canada
}

Keywords: Litter bags, aquatic macrophytes, autumn-shed leaves, decomposition of fresh and dried detritus, leaching

\section{SUMMARY}

The bulk of vascular plant production in terrestrial or aquatic habitats enters the detrital carbon pool. Microorganisms initiate incorporation of the detritus into food webs. Following the icad by soil ecologists, limnologists have investigated decomposition by exposing dried plant parts in litter bags. Under these conditions. leaching (rapid, abiotic loss of soluble compounds such as phenolics, carbohydrates, amino acids) is common. Leaching is largely absent when fresh, rather than predried, alder aiid willow leaves are exposed in water. Reduced leaching was subsequently shown to delay colonization by aquatic hyphoinycetes and invertebrate feeding. In a series of experiments with 27 leaf species (some species tected more than once), drying significantly increased leaching in 18 cases, had no effect in 3 caces, and decreased leaching in 8 cases. Many aquatic inacrophytes that contribute to the organic budget of rivers and streams do not abscise their leaves or stems. This includes Bryophyta (e.g., Fontinalis sp.), submerged (e.g., Ranunculus sp.) and emergent (Typha sp.) vascular planta. Almost without exception, decomposition of such plant material has been studied by removing and drying plant parts followed by their exposure in litter bags. Based on comparable studies from marches, it is likely that this introduces several sources of error: the course and magnitude of leaching may change. and there may be shifts between inicrobial groups (fungi vs. bacteria). To avoid some of these piffalls, it is essential to closely observe the natural introduction of detritus into streams and conditions during its decay, and attempt to reproduce these conditions during experiments.

\section{INTRODUCTION}

Production in many terrestrial and aquatic ecosystems is dominated by vascular piants (WESTLAKE, 1963: WETZEL. 1990). Consumption of living vascular plant material is often minimal, and the bulk of the primary production enters the detrital, or non-iiving, carbon pool. It is generally assumed that microorganisms, primarily fungi and bacteria, initiate incorporation of this detritus into food webs. Microbial decomposition is therefore a key procese. and has been studied extensively. Most investigations have been based on a technique pioneered by terrestrial ecologists come 60 years ago (FALCONER et al.. 1933: LUNT, 1933): plant material is coilected, dried (sometimes at room temperature, more often in an oven). and preweighed portions are exposed in containerc such as boxes, openended tubes, or, most commonly, in litterbags with variable mesh sizes. Periodically, some containers are recovered, the remaining mass of the detritus is determined and chemicai analysea are performed. Thic approach obviously deviates in several ways from the natural decomposition process and may

Limnefica, $13(2): 1-11$ (1997)

J. Poro \& A. Elosegi (eds),

Proceedings of the European Meeting on Litter Breakdown in Rivers and Streams ค. Asociación Española de Limnología, Madrid, Spain. lead to erroneous conclusions concerning the course of decomposition and the relative contributions of fungi and bacteria. In thic review, I shall discuss two potential sources of error. The first concerns the use of pre-dried plant materials. and the second the confinement in litterbagc of detritus that normally remains attached to the plant beyond senescence and death. Decay in the "standing-dead" phace predominates in grasses and grass-like piants.

\section{AUTUMN-SHED LEAVES}

\section{Leaching in dried and fresh leaves}

Leaching refers to the rapid, abiotic removal of soluble compounds from plant litter. One of the first thorough investigations of this process was conducted by NYKVIST (1963). He worked with several cpecies of air-dried leaves, and found that they lost between 7.1 (Quercus robur) and 16.5\% (Fraxinus excelsior) of their total mass within one day of being submerged in distilled water. Leaching losses were much lower from conifer 
needles (for example, $0.9 \%$ in Pinus silvestris). NYKVIST (1963) also demonstrated that leaching is accelerated when the leaves or needles are first ground into smaller particles. Amino acids, sugars and fatty acids together accounted for $10-25 \%$ of the total organic leachate. Among other potential components, which he did not analyze, NYKVIST (1963) mentioned watersoluble phenolics. When leachates were stored under aerobic conditions, "clots" of bacteria, fungal hyphae and protozoa appeared within a few days, apparently sustained by the dissolved organic compounds. Under anaerobic conditions, only bacteria could be observed. Obviously, leached substances make up a substantial portion of total leaf mass, and their retention or removal is likely to affect organisms that feed on the leaf, as well as organisms that depend on nutrients dissolved in water.

NYKVIST was interested in how leaching would affect soil formation, but autumn-shed leaves also make an important contribution to food webs in streams (BIRD \& KAUSHIK, 1981; BARLOCHER, 1992 a). In a pioneering study of leaf breakdown in streams, KAUSHIK \& HYNES (1971) differentiated between an early, rapid loss due to leaching, followed by a more gradual loss due to microbial and invertebrate attack. This distinction became generally accepted, and leaf decomposition in streams has been suhdivided into three more or less distinct phases: leaching, microbial colonization and invertebrate feeding (CUMMINS, 1974). Leaching in streams is generally complete within $24-48 \mathrm{~h}$ and results in a loss of up to $30 \%$ of the original mass (WEBSTER \& BENFIELD, 1986). SUBERKROPP et al. (1976) identified phenolics and soluble carbohydrates as two classes of organic compounds that are particularly susceptible to leaching.

In order to achieve more uniform initial conditions, leaves were almost always dried at room temperature or in an oven before their decomposition was studied. GESSNER \& SCHWOERBEL (1989) demonstrated that this pretreatment greatly increased mass losses of alder (Alnus glutinosa (L.) Gaertner) and willow (Salix fragilis L.) leaves during the first few days. Fresh, i.e. non-dried, leaves did not lose any appreciable mass during the first few days of immersion.

GESSNER \& SCHWOERBEL (1989) attributed their observations to the fact that the shedding of leaves is preceded by senescence, which is an orderly process, requiring maintenance of the cell's compartments and functioning biochemical processes (MATILE, 1986). Death of the leaf generally occurs when phenolic compounds are released from vacuoles and make contact with phenoloxidases, resulting in the browning of the leaf. Autumn-shed leaves of alder and many other trees are not necrotic upon abscission and largely maintain their integrity (there is recent evidence, however, that to some extent membra- nes do deteriorate during senescence, resulting in increased leakage; THOMPSON et al., 1997). Drying, however, is known to disrupt internal membrane structures and to increase leakage of solutes through the plasmalemma (BEWLEY, 1979). Drought intolerant plants are unable to reverse these changes, which lcads to increasing fragmentation of organelles and membrane structures.

The observation that leaching in fresh (non-dried) leaves is much reduced has potentially far-reaching consequences (GESSNER, 1991). The cubstances retained by the leaf (amino acids, carbohydrates, phenolics, etc.) may influence its colonization by aquatic microbes and palatability to stream invertebrates. Conversely, a reduced supply of leaf leachate to the stream water would presumably have negative effects on the activity of planktonic bacteria (CUMMINS et al., 1972) and of biofilm communities (associations of bacteria, fungi and protozoa embedded in polysaccharide matrices, covering most solid/water interfaces; LOCK, 1993). I am not aware of any study comparing the effect of dried and non-dried leaves on such "extemal" microbes, but there are some data on microbial colonization and invertebrate consumption of fresh and dried leaves.

In a field study started on 19 September, fresh A. glutinosa leaves lost less mass than dried leaves during the first four weeks of exposure in the River Teign in Devon, England. Over the entire course of the study (11 weeks), the decay rates did not differ significantly (BARLOCHER, 1991). Similarly, colonization by aquatic hyphomycetes proceeded more rapidly on dried leaves than on fresh leaves. After two weeks in the stream, recovered dried leaves released close to 5000 conidia per $\mathrm{mg}$ leaf mass during two days of aeration; only 40 were recovered from fresh leaves. There was some indication that oomycetes were more common on fresh than on dried leaves during the first two weeks.

When the experiment was repeated on 14 November, there were no longer significant differences between fungal colonization and mass losses during the first few weeks (BARLOCHER, 1991). One possihle explanation was based on the fact that between the two experiments, the air temperature had repeatedly dropped below freezing. Like desiccation, freezing can disrupt the integrity of leaves and damage their membranes, which may result in increased leakage (BURKE et al., 1976). A third experiment was therefore initiated in the following spring: young, green leaves were collected, exposed in a stream without further treatment or first dried or frozen. Colonization by aquatic hyphomycetea was delayed on fresh leaves, but not on frozen or dried leaves. The conclusion was that drying or freezing accelerates leaching of suhstances that 
inhibit fungal colonization. This was tested by extracting variously treated leaves with distilled water, and exposing aquatic hyphomycetes to these leachates (BARLOCHER, 1990). As expected, leachates from whole, fresh leaves did not inhibit fungal growth, while leachates from whole, dried leaves did.

Leachates contain amino acids, sugars, phenolics and aliphatic acids. Some of these compounds are valuable nutrients, while others are known to deter potential consumers. It is therefore conceivable that fresh, unleached leaves are more attractive to invertebratec. There is little evidence that this is the case (BÄRLOCHER, 1990; CHERGUI \& PATTÉE, 1993; GESSNER \& DOBSON, 1993). Neither Gammarus pulex (Amphipoda) nor Asellus aquaticus (Isopoda) discriminated between leached dried and unleached fresh $\boldsymbol{A}$. glutinosa leaves, but both strongly preferred conditioned (colonized by aquatic hyphomycetes) over unconditioned leaves (BARLOCHER, 1990). In a related study, STOUT et al. (1985) found no evidence for invertebrate feeding on fresh summer leaves (Alnus rugosu) until 26 days after immersion in two hardwater streams in Michigan. Nevertheless, a diverse macroinvertebrate community invaded fresh leaf packs during this initial period. STOUT et al. (1985) suggest that fresh leaves might support a rich epiphyllic community of fungi, bacteria, algae, protozoa and micrometazoa. This biofilm, in turn, could attract invertebrate "browsers". ROUNICK \& WINTERBOURN (1983) demonstrated that organic layers of slime, fine particles and microbes are potential food sourcec for stream invertebrates, and that leaf leachates enhance the thickness of this layer. Since fresh leaves retain soluble substances, a biofilm may form on the leaves themselves. STOUT et al. (1985) commented that fresh leaves were "more slimy" to the touch than were autumn leaves during the first 26 days. This indicates a superficial microbial film, possibly sustained by slow leakage of organic molecules from the leaf. STOUT et al. (1985) used summer leaves, and they suggest that cellular activity, including photosynthesis, may have continued in the stream. GESSNER \& DOBSON (1993) found no significant differences in invertebrate colonization of fresh and dried A. glutinosa litter. However, invertebrate numbers peaked four weeks after immersion of the leaves. By then, chemical differences between fresh and dried leaves may have become negligible (GESSNER, 1991).

GESSNER (1991) compared the decomposition of fresh and dried $\boldsymbol{A}$. glutinosa leaves during the first eight weeks in a stream. As expected, he observed an early sharp decline in the mass of dried but not of fresh leaves. In addition to soluble organic compounds, phosphorus and potassium also leached rapidly from dried leaves. Dynamics of nitrogen and protein were similar in the leaf types, which GESSNER (1991) interpreted to mean that microbial colonization was not greatly delayed in fresh leaves. Combined with the observation that cellulose decay was initially slower in fresh leaves, this suggests that early microbial colonizers of fresh leaves used the labile organic compounds that were leached from dried leaves. In addition, phenolics and tannins in fresh leaves probably contributed to the formation of artifact lignins (complexes of phenolics, polysaccharides and proteins); due to rapid leaching, no such effect was observed in dried leaves. The stability of such artifact lignins depends, among other factors, on $\mathrm{pH}$; they may therefore be a source of food for invertebrates with highly alkaline gut fluids such as Tipula larvae (BARLOCHER et al., 1989).

It may be argued that the distinction between dried and fresh leaves becomes irrelevant in hot climates. Thus, in Alabama, leaves of Liriodendron tulipifera $\mathrm{L}$. often become dry and brittle while still attached to the tree (K. SUBERKROPP, pers. comm.). In Basel, Switzerland, newly shed leaves of the same species generally have retained much of their moisture and remain rubberlike (pers. obs.). Nevertheless, the only published study from a subtropical region, Morocco, also showed clear differences between fresh and dried willow leaves (Salix sp., later identified as. S. pedicellata; CHERGUI \& PATTÉE, 1992; 1993). The rapid initial mass loss, assumed to be due to leaching, wac absent in fresh leaves, and during the first two months spore production and fungal species numbers were higher on dried leaves. The gastropod shredder Melanopsis praemorsa initially preferred dried leaves, and its mortality was higher on fresh leaves. These observations again suggest that the soluble compounds that are leached from dried but not from fresh leaves have an overall inhibitory effect on aquatic hyphomycetes and leaf-eating invertebrates. As in other studies, decay rates over the entire study period (17 wks) did not differ significantly between fresh and dried leaves. Average monthly air temperature during leaf fall at the Moroccan sites was approx. $20^{\circ} \mathrm{C}$, with extremes between $12-28^{\circ} \mathrm{C}$ (E. PATTÉE, pers. comm.), which is considerably higher than temperatures in Central Europe.

When fungal colonization is delayed, changing external conditions may affect fungal succession. In temperate deciduous forests, the shedding of leaves coincides with falling temperatures (in temperate evergreen forests, dominant in the southern hemisphere, leaf fall occurs in summer, when water temperatures are high; CAMPBELL \& FUCHSHUBER, 1994). As a consequence, species preferring higher water temperatures would benefit if leaves were predried, and be less common if leaves were introduced in a natural, fresh state. This was shown to occur in the River Teign: Lunulospora curvula, a species generally more common at warmer temperatures (WEBSTER et al., 
1976), dominated on dried leaves introduced on 19 Septernher: on frech leaves, where fungal colonization was delayed by several weeks, it never reached the same dominance (BARLOCHER, 1991). During the experiment, the water temperature dropped from 11.5 to $3.1^{\circ} \mathrm{C}$.

In a similar study in the French Pyrenees, fungal colonization of fresh A. glutinosa leaves was again delayed (GESSNER rt al., 1993). In one year, correspondence analysis demonstrated a slight difference in the fungal communities of fresh and dried leaves. In the second year, no difference was found. This may be due to the fact that the study was done in a "sumnier cool" stream, and Lunulospora curvula and other species typical of warm streams were absent (GESSNER et al., 1993).

In the Moroccan streams, a total of 16 species were found on pre-dried leaves, vs. 12 on fresh leaves (CHERGUI \& PATTÉE. 1993).

Thus, several studies have shown that in fresh (non-dried) leaves of $\boldsymbol{A}$. glutinosa and Salix sp., leaching will be reduced, and fungal colonization and invertebrate consumption delayed. One factor that might simulate drying is exposure to freezing temperatures. Two questions remain: how much of the annual leaf production enters streams in a fresh state. and do all lcaf species react in a similar manner to drying?

From the limited information available, it appears that in temperate deciduous forests, a majority of leaves will enter the stream immediately after being separated from the tree (primarily through natural abscission during fall, but see below; FISHER, 1977; CONNERS \& NAIMAN, 1984). Conditions are likely to be more variable in subtropical and tropical regions: some species lose a small proportion of their leaves throuphout the year, others lose them as the dry season approaches, a third group drops them after the onset of the rainy season (COVICH. 1988; SRIDHAR et al., 1992). As a consequence, some leaves may accumulate on temporarily dry ground. In a Puerto Rico rainforest, terrestrial basidiomycetes reduced downhill movements of leaves on steeply sloped stream hanks by $40 \%$ (LODGE \& ASBURY. 1988). Aerial rhizomorphc of Marasmius, Psathurella and others function much like spider webs and entrap leaves before they reach the ground (HEDGER. 1990; COVICH. 1988). This may again introduce an aerial phaae of decomposition before the leaves reach a stream.

In temperate deciduous forests, a variable proportion of the leavec becomes detached while still green due to storms or due to insect damage (BRAY \& GORHAM, 1964). Often, young leaves are less well defended against herbivores than older leaves (CHOUDHOURY, 1988). It is therefore conceivable that the effects of increased leaching (which may remove inhibitory compounds) on fungal colonization are age-specific. This seems to be supported by the observation that drying of Betula papyrifera aiid Acer saccharum leaves collected very early in the season had no effect on fungal colonization (SRIDHAR \& BÄRLOCHER, 1993).

In evergreen temperate forests, leaf fall is less seasonal and dominated by abscission. There ceems to be little overland transport of fallen leaves from dry areas into streams (CAMP. BELL et al., 1992); leaves decaying in streams are therefore unlikely to have experienced a lengthy phase of aerial decompocition.

Do most leaves remain "fresh" until abscission, i.e., do they maintain thcir structural integrity? One would assume that in conifers and deciduous species that retain senescent or dead leaves for extended periods of time (for exaniple, oak and beech), additional drying before decomposition experirrients has little effect. Species of Eucalyptus and Acacia are common in arid climates and presumably have adapted to retain moisture under these conditions. Whether these mechanisms remain effective during senescence and abscission is unknown.

In a Canadian study with three species (Betula papyrifera, Ulmus americana and Acer saccharum), hoth drying and freezing increased leaching (BARLOCHER, 1992 b). However, leaching was not completely ahcent in fresh leaves of the same species, and exceeded $10 \%$ in U. americana. This very pronounced leaching may have been due to the fact that a substantial proportion of the elm leaves were visibly damaged by insect feeding. This raises another important point: it is often standard practice to use unblemished leaves in decomposition studies. As pointed out by BOULTON \& BOON (1991), this may give misleading information in systems where heavy feeding by insects or other herbivores is common (CHOUDHOURY, 1988).

In the most extensive ctudy puhlished to date, leaching of fresh and pre-dried leaves from 27 species, collected across Canada. wac compared (TAYLOR \& BARLOCHER. 1996). Some leaves were collected from more than one location or in two successive years, giving a total of 35 measurementc. No attempt was made to select healthy or undamaged leaves, but most leaves, with the exception of Alnus crispa (Ait.) Pursh and Sorbus americana Marsh., were largely free of conspicuous insect damage or necrosis (some leaves, however, were sticky. indicating that some "leaching" rnay have been due to washing off of external compounds). In slightly more than half of the cases ( 18 out of 35), air-drying significantly increaced leaching losses: in another 7 cases, it decreased leaching, and in 10 cases it had no significant effect. The most credible explanation for decreased leaching is that complexation and precipitation of cell components occurred during drying. Neither moisture content. nor leaf or cuticle thickness proved useful as predictors of 
leaching losses or the effect of air-drying. It seems that both magnitude and direction of changes in leaching due to drying may be highly variable, not just between species, but also within species collected in different years, or at different sites. Factors that intluence leaching patterns may include the extent of insect damage, temperature and availability of nutrients and water during growth and senescence. The nature of the leachable material may be as important as its quantity in affecting the course of decomposition, colonization by aquatic hyphomycetes and invertebrates, and those microbes not directly associated with the leaves.

\section{Exposure techniques}

Once the leaves have been collected, they have to be exposed in a stream. There are essentially three techniques: 1. unconstrained leaves; 2 . stacking leaves on top of each other and loosely sowing them together into packs; 3 . placing leaves in bags with variable mesh sizes. A thorough discussion of the relative merits of these approaches is beyond the scope of this paper; a useful review can be found in BOULTON \& BOON (1991). Measuring decay in unconstrained leaves most closely approximates the natural process, but ic difficult in practice (CUMMINS et al., 1980; BENFIELD et al., 1991; D'ANGELO \& WEBSTER, 1992; GRUBBS \& CUMMINS, 1994). It generally results in higher estimated rates of mass loss than studies with leaf packs or bags, precumably because direct exposure to the current maximizes mechanical fragmentation. Packs of leaves held together with nylon filament or staples and tethered to objects within the stream allow free access to invertebrates and are considered a reasonable compromise between realism and reproducibility. However, decay rates depend on the size of leaf packs (REICE, 1974; CAMPBELL et al., 1994); in streams, leaf accumulations continuously form and reform, and it is therefore difficult to define a representative pack size. In addition, packs are often attached to bricks; if large numbers are introduced in a stream reach, current patterns, and microbial and invertebrate colonization inay be profoundly influenced. Finally, litter bags may drastically lower the impact of the current on the enclosed leaves, and depending on mesh size, restrict the access of invertebrates. Nutrient and gas exchange, and therefore microbial metabolism, may also be inhibited.

When deciding on which exposure method to use, it is essential to clearly define the objectives of the study. If the goal is broadly descriptive, i.e., to determine how leaf material is transferred to various compartineiits such as dissolved organic matter, fungal and bacterial biomass, etc.. an investigation of unronstrained leaves should give the most accurate results. It is iinportant to realize, however, that this approach can be enormously time-consuming, especially if one wants to compare several streams with species-rich riparian vegetation. Variability will be high, which inevitably lowers the power to detect patterns and identify iinportant factors. In many cases, a more successful strategy involves focusing on relatively narrow, welldefined questions, which can generally be investigated adequately under less realistic, but better controlled conditions.

\section{EMERGENT FRESHWATER AND ESTUARI- NE MACROPHYTES}

\section{Leaching of fresh and dried detritus}

Freshwater and estuarine marshes have long been recognized as being among the most productive ecocystems (WESTLAKE, 1963).Much of their productivity is due to emergent macrophytes of the littoral zone, dominated by genera such as Typha, Phragmites, Scirpus and Spartina (WETZEL, 1990; NEWELL. 1993). In freshwater and estuarine streams, they are generally restricted to banks and shoals (HYNES, 1970; ALLAN, 1995). but additional material may be swept in from upstream or by tides. There are literally hundreds of studies investigating the decomposition of emergent macrophytes (for reviews, see POLUNIN, 1984; NEWELL, 1993; GESSNER et al., 1997). The vast majority is based on the use of pre-dried material (e.g., MASON \& BRYANT, 1975; ANDERSON. 1978; GODSHALK \& WETZEL, 1978 a, b, c; MORRIS \& LAJTHA, 1986; CHERGUI \& PATTÉE, 1990). Some studies reported faster leaching of organic carbon due to drying, but as with deciduous leaves, this effect is not universal (GODSHALK \& WETZEL, 1978 a; LARSEN, 1982; ROGERS \& BREEN, 1982). Generally, leaching became more pronounced when dried material was cut or ground into small particles (BRUQETAS DE ZOZAYA \& NEIFF, 1991; OLÁH, 1972). In two recent ctudies with Spartina alterniflora (SAMIAJI \& BARLOCHER, 1996), Typha latifolia and Lythrum salicaria (BARLOCHER \& BIDDISCOMBE, 1996), total mass loss and loss ofsugars and phenolics were generally higher during the first $1-2$ wks in predried leaves, indicating that leaching was less pronounced in frech leaves. Dissolved organic carbon is the dominant form of organic carbon in most aquatic ecosystems (WETZEL, 1983; THURMAN. 1985), and accurate knowledge of how and when it is introduced into the water is clearly important.

\section{Exposure techniques}

The earliest studies of decomposition in inarshes were based 
on cut and dried plant parts, which were permanently submerged in boxes or litter bags, or on ground up leaves incubated in water with marsh sediment (for reviews, see POLUNIN, 1984; NEWELL, 1993). Under these conditions, bacteria often predominate and the fungal contribution to decay was assumed to be negligible (TEAL, 1962; BENNER et al., 1986; MORAN et al., 1988; for notable exceptions, see MASON, 1976; MASON \& BRYANT, 1975). Mycologists, on the other hand, were well aware of the diverse mycoflora that can be found on Spurtina, Typha, Phragmites and other marsh plants (INGOLD, 1955; APINIS \& CHESTERS, 1964; PUGH \& MULDER, 1971; TALIGOOLA et al., 1972; APINIS et al., $1972 \mathrm{a}$, b; GESSNER \& GOOS, 1973; KOHLMEYER \& KOHLMEYER, 1979; ELLIS \& ELLIS, 1985). Surprisingly, DESJARDIN et al. (1995) even found a psychrophilic agaric on culms of Scirpus californicus submerged under a thin layer of ice. The real breakthrough, however, came with the recognition that most emergent macrophytes do not abscise leaves or stems. NEWELL \& FALLON (1989) and NEWELL et al. (1989) were the first to systematically apply this insight by comparing the decomposition of dried Spartina alterniflora leaves in litterbags with that of standing leaves marked with electric cable ties. They concluded that ascomycetous fungi dominate the microbial biomass that accumulates on naturally decaying leaves. Fungi captured up to $90 \%$ of the nitrogen present in decaying S. alterniflora leaves within 8 - 10 wks.

In North America, Spartina salt marshes extend from Texas (latitude $27^{\circ}$ ) all the way to the Gulf of St. Lawrence (latitude $46^{\circ}$; MANN, 1982). Conceivably, the natural action of ice and snow during late fall and winter at higher latitudes might simulate to some extent decay of detached leaves, and the study of detritus in litter bags might be a close approximation of the natural process. A recent study in a New Brunswick marsh (latitude $45^{\circ}$ ) showed that this is not the case (SAMIAJI \& BARLOCHER, 1996). The decay of over $80 \%$ of leaves formed during a growing season is initiated while they are still attached and upright. On such leaves, fungal biomass (as estimated by ergosterol) is again considerably higher than that on dried leaves placed in litterbags.

On the European side of the North Atlantic and in other parts of the world, the marsh flora is much more diverse and heterogeneous (MANN, 1982). There are several studies of the decay of Spartina anglica, $S$. townsendii and $S$. maritima (for example, POZO \& COLINO, 1992), but to my knowledge they are all based on dried material exposed in litterbags. BARATA $t$ al. (1997) recently described a new fungal species from Spartina maritima in the Mira River estuary (Portugal), suggesting that a closer look at the role and diversity of fungi on
European salt marsh macrophytes will be rewarding.

NEWELL (1993) wrote: "Researchers interested in accurately describing natural microbial participation in the decay of portions of vascular plants must try to avoid altering genuine conditions of decay via their methods". It seems obvious that this reasoning also applies to freshwater marshes. This was stated explicitly by DAVIS \& VAN DER VALK (1978): “Any study of emergent macrophyte decomposition ...must recognize the fact that the processes involved begin in an aerial environment and conclude in an aquatic environment." These authors compared mass loss of macrophyte detritus in litterbags suspended in the air and in the water, but did not measure bacterial and fungal biomass or activity. The first published attempt to simulate the natural process by studying Carex leaves decaying in situ again demonstrated that fungal standing crop and productivity greatly exceeded those of bacteria during the initial, aerial stage of decay (NEWELL et al., 1995). Naturally decaying Typha leaves accumulated considerably more ergosterol than pre-dried leaves submerged in litterbags (BARLOCHER \& BIDDISCOMBE, 1996). The same trend was found with leaves of the purple loosestrife (Lythrum salicaria L.), which, however, started to shed leaves at an exponential rate after senescence. For this particular plant, therefore, placing leaves (preferably undried) in a litterbag is unlikely to misrepresent the natural process to the same extent as it would in Typha or Spartina.

KUEHN (1997) made an important addition to our understanding of decay in freshwater macrophytes by measuring daily variation of microbial respiration. In Alabama, day temperature during summer can reach $36{ }^{\circ} \mathrm{C}$. Under these conditions, $\mathrm{CO}$, release is close to 0 . After nightfall, temperature drops to values in the low 20s, and air humidity increases. This in turn allows considerable microbial respiration and release of fungal spores. Most previous studies were conducted during the day, and therefore missed this very significant contribution of primarily fungal respiration to the overall carbon budget.

\section{OTHER PLANTS}

In addition to emergent plants, there is a variety of other macrophytes that can make important contributions to the detritus food webs in aquatic habitats. They are generally grouped into three broad categories, namely floating-leaved taxa, freefloating plants, and submerged taxa (HYNES, 1970; HASLAM, 1978; ALLAN, 1995). NEWMAN (1991) compared evidence for herbivory vs. detritivory for some of these plants, and concluded that many seem to be protected by feeding deterrents. Such deterrents often persist beyond senescence and death, and may have antimicrobial properties. Treatments that influence 
leaching dynamics, and therefore the removal of such compounds, may profoundly alter the course of decomposition and the relative contributions of bacteria and fungi. Since for the most part these plants remain covered by water throughout growth and decomposition, pre-drying is very likely to introduce artifacts, and ideally should be avoided. However, it is often difficult with partly or wholly submersed plants to distinguish between living, senescent and dead sections. Instead of decaying, collected and exposed material may actually grow. To prevent this, several authors used frozen plants (BARTODZIEJ \& PERRY, 1990; NEWMAN, 1990), but cell death upon thawing is likely to have the same effect as drying. KORNIJOW et al. (1995) worked with material that had been incubated in the dark for 7 days at $35^{\circ} \mathrm{C}$.

Most studies were again done with pre-dried leaves or leaf sections in litter bags. For example, GAUR et al. (1992) compared fungal and bacterial contributions to water hyacinth (Eichhornia crassipes) decomposition by using air-dried tissue. IKUSIMA \& GENTIL (1996) dried water lily leaves to investigate leaching. KOK et al. (1990) used frozen disks for decomposition experiments, while KOK \& VAN DER VELDE (1994) prepared disks from leaves stored at $4{ }^{\circ} \mathrm{C}$. I am not aware of any study that tried to imitate the natural breakdown of water lilies by tagging leaves and estimating mass loss, and fungal and bacterial biomass. Fungi do occur on water lily leaves, both as saprophytes (KOK et al., 1992) and as pathogens (JOHNSON et al., 1997), and the large size and obvious signs of senescence in this plant should make a more realistic approach to studying decomposition feasible.

HANLON (1982) noticed that two macrophytes, Isoetes lacustris L. and Potamogeton perfoliatus L. became extremely fragile when oven dried. He therefore worked with air-dried material, while CHERGUI \& PATTÉE (1990) used Potamogeton leaves dried at $40{ }^{\circ} \mathrm{C}$.

GODSHALK \& WETZEL (1978 a, c) worked with a variety of floating-leaved (Nuphar variegatum) and submersed plants (Myriophyllum heterophyllum, Najas flexilis, Zostera marina). They measured release of dissolved components from air-dried material.

\section{CONCLUSIONS}

The current review discusses two widespread practiccs that may give a misleading picture of how deconiposition procecds in iiature: the use of pre-dried material, and exposure of thic material under conditions that deviate significantly from reality. The severity and direction of artifacts that may be introduced vary hetween systems, and generalizations are difficult.
Reasonably consistent results have been found with Alnus glutinosa and Salix sp. decaying in streams: pre-dried leaves lose soluble organic compounds much more rapidly than fresh leaves, and are more readily coionized by aquatic hyphomycetes, which in turn makes them more quickly acceptable to leafeating invertebrates. In a comprehensive study with other leaf species, the results were often contradictory: in roughly haif of the reported cases, drying also increased leaching; in the remaining cases, there was either no change or the opposite effect was observed. More progress probably depends on a closer look at how different ciasses of compounds are affected by drying.

With emergent macrophytes in freshwater or estuarine marshes, it seems equally clear that early studies. based on dried material in litterbags, underestimated fungal participation. There is an entire fungal community specifically adapted to the cyclical changes of temperature, humidity and salinity. Even in hot climates, daily fluctuations are sufficient to allow temporary resumption of fungal activity.

For submersed plants, there is insufficient information of how decomposition might proceed under natural conditions. Since they are generally delicate and often small, it is difficult to recognize and tag senescent parts, and a simulation of natural decay presents formidable challenges.

Ciose adherence to natural conditions of decay is most important when the goal is some kind of description and quantification of microbial groups responsible for natural decay, and to follow the fate of the various detritus fractions. In these cases, there is simply no substitute for carefully observing the natural process, and trying to imitate it as faithfully as possible. In many other cases, the question of interest may be much more circumscribed, and deviations from the "normal' conditions may be acceptable, or even desirable.

\section{ACKNOWLEDGEMENTS}

I acknowiedge with gratitude advice from E. Pattee and K. Suberkropp during the writing of this review. I'm thankful to the organizers of this meeting for financial support.

\section{REFERENCES}

ALLAN, J.D., 1995. Stream ecology. Chapman \& Hall. London.

ANDERSON, F.O.. 1978. Effects of nutrient level on the decomposition of Phragmites communis Trin. Arch. Hydrobiol., 84: 42-54.

APINIS, A.E. \& C.G.C.CHESTERS, 1964. Ascomycetes of some salt marshec and sand dunes. Trans. Br. Mycol. Soc. 47: 
419-435.

APINIS, A.E., C.G.C. CHESTERS \& H.K. TALIGOOLA, 1972 a. Colonization of Phragmites communis Trin. leaves by fungi. Nova Hedwigia, 23: 113-124.

APINIS, A.E., C.G.C. CHESTERS \& H.K. TALIGOOLA, $1972 \mathrm{~b}$. Microfungi colonizing submerged standing culms of Phragmites communis Trin. Nova Hedwigia, 23: 473-480.

BARATA, M., M.C. BASILIO \& J.L. BAPTISTA-FERREIRA, 1997. Nia globospora, a new marine gasteromycete on baits of Spartina maritima in Portugal. Mycol. Res., 101: 687690.

BARLOCHER, F., 1990. Factors that delay colonization of fresh alder leaves by aquatic hyphomycetes. Arch. Hydrobiol., 119: 249-235.

BARLOCHER, F., 1991. Fungal colonization of fresh and dried alder leaves in the River Teign (Devon, England). Nova Hedwigia, 52: 349-357.

BARLOCHER, F., 1992 a. Research on aquatic hyphomycetes: historical background and overview. In: The ecology of aquatic hyphomycetes. (E BARLOCHER, ed.): 1-15. SpringerVerlag, Berlin.

BARLOCHER, F., 1992 b. Effects of drying and freezing autumn leaves on leaching and colonization by aquatic hyphomycetes. Freshwat. Biol., 28: 1-7.

BARLOCHER, F. \& N.R. BIDDISCOMBE, 1996. Geratology and decomposition of Typha latifolia and Lythrum salicaria in a freshwater marsh. Arch. Hydrobiol., 136:309-325.

BARLOCHER, F., P.G. TIBBO \& S. CHRISTIE, 1989. Formation of phenol-protein complexes and their use by two stream invertebrates. Hydrobiologia, 173: 243-249.

BARTODZIEJ, W. \& J.A. PERRY, 1990. Litter processing in diffuse and conduit springs. Hydrobiologia, 206: 87-97.

BENFIELD, E.F., J.R. WEBSTER, S.W. GOLLADAY, G.T. PETERS \& B.M. STOUT, 1991. Effects of forest disturbance on leaf breakdown in southern Appalachian streams. Verh. Int. Ver: Limnol., 24: 1687-1690.

BENNER, R., M.A. MORAN \& R.E. HODSON, 1986. Biogeochemical cycling of lignocellulosic carbon in marine and freshwater ecosystems: relative contributions of procaryotes and eucaryotes. Limnol. Oceunogr., 31: 89-100.

BEWLEY, J.D., 1979. Physiological aspects of desiccation tolerance.Ann. Rev. Pl. Physiol., 30: 195-238.

BIRD, G.A. \& N.K. KAUSHIK, 1981. Coarse particulate organic matter in streams. In: Perspectives in running water ecology. (M.A LOCK \& D.D. WILLIAMS, eds.): 41-68. Plenum Press, New York.

BOULTON, A.J. \& P.I. BOON, 1991. A review of the methodology used to measure leaf litter decomposition in lotic environments: time to turn over an old leaf? Austr. J. Mar. Freshw. Res., 42: 1-43.

BRAY, J.R. \& E. GORHAM, 1964. Litter production in forests of the worlds. Adv. Ecol. Res., 2: 101-157.

BRUQUETAS DE ZOZAYA, I. Y. \& J. J. NEIFF, 1991. Decomposition and colonization by invertebrates of Typha latifolia L. litter in Chaco cattail swamp (Argentina). Aquat. Bot., 40: 185-193.

BURKE, M.J., L.V. GUSTA, H.A. QUAMME, C.M. WEISTER \& P.H. LI, 1976. Freezing and injury in plants. Ann. Rev. Pl. Physiol., 27: 507-528.

CAMPBELL, I.C. \& L. FUCHSHUBER, 1994. Amount, composition and seasonality of terrestrial litter accession to an Australian cool temperate rainforest stream. Arch. Hydrobiol., 130: 499-5 12 .

CAMPBELL, I.C., K.R. JAMES, B.T. HART \& A. DEVEREAUX, 1992. Allochthonous coarse particulate organic material in forest and pasture reaches of two southeastern Australian streams. 1. Litter accession. Freshwat. Biol., 27: 341-352.

CAMPBELL, I.C., G.M. ENIERGA \& L. FUCHSHUBER, 1994. The influence of pack size and position, leaf type, and shredder access on the processing rate of Atherosperma moschatum leaves in an Australian cool temperate rainforest stream. Int. Rev. ges. Hydrobiol., 19: 557-568.

CHERGUI, H. \& E. PATTÉE, 1990. The processing of leaves of trees and aquatic macrophytes in the network of the River Rhone. Int. Rev. ges. Hydrobiol., 75: 281-302.

CHERGUI, H. \& E. PATTÉE, 1992. Processing of fresh and dry Salix leaves in a Moroccan river system. Acta Oecol., 13: 291-298.

CHERGUI, H. \& E. PATTÉE, 1993. Fungal and invertebrate colonization of Salix fresh and dry leaves in a Moroccan river system. Arch. Hydrobiol., 127: 57-72.

CHOUDHOURY, D., 1988. Herbivore induced changes in leaf-litter resource quality: a neglected aspect of herbivory in ecosystem nutrient dynamics. Oikos, 51:389-393.

CONNERS, M.E. \& R. NAIMAN, 1984. Particulate allochthonous inputs: relationships with stream-size in an undisturbed watershed. Can.J. Fish. aquat. Sci., 41 : 1473-1484.

COVICH, A.P., 1988. Geographical and historical comparisons of neotropical streams: biotic diversity and detrital processing in highly variable habitats. J. N. Am. Benthol. Soc., 7: 361 386.

CUMMINS, K.W., 1974. Structure and function of stream ecosystems. BioScience, 24: 61-64.

CUMMINS, K.W., J.J. KLUG, R.G WETZEL, R.C. PETERSEN, K.F. SUBERKROPP, B.A. MANNY, J.C. WUYCHECK \& F.O. HOWARD, 1972. Organic enrichment with leaf leachate 
in experimental lotic ecosystems. BioScience, 22: 719-722.

CUMMINS, K.W., G.L. SPENGLER, G.M. WARD, R.M. SPEAKER, R.W. OVINK, D.C. MAHAN \& R.L. MATTINGLY, 1980. Processing of confined and naturally entrained leaf litter in a woodland stream ecosystem. Limnol. Oceanogr., 25: 952-957.

D'ANGELO, D.J. \& J.R. WEBSTER, 1992. Natural and containment-induced factorc influencing the breakdown of dogwood and oak leaves. Hydrohiologia, 237: 39-46.

DAVIS, C.B. \& A.G. VAN DER VALK, 1978. The decomposition of standing and fallen litter of Typha glauca and Scirpus fluviatalis. Can.J. Bot., 56: 662-675.

DESJARDIN, D.E., L. MARTÍNEZ-PECK \& M. RAJCHENBERG, 1995. An unusual psychrophiiic aquatic agaric from Argentina. Mycologia, 87: 547-550.

ELLIS, M.B. \& J.P. ELLIS, 1985. Microfungi on land plants. Macmillan Publishing Company, New York.

FALCONER, G. J., J.W. WRIGHT \& H. W. BEALL, 1933. The decomposition of certain types of fresh litter under field conditions. Am. J. Bot., 20: 196-203.

FISHER, S.G., 1977. Organic matter processing by a stream segment ecosystem: Fort River, Massachusetts, USA. Inter. Rev. ges. Hydrobiol.. 62: 701-727.

GAUR, S., P.K. SINGHAL \& S.K. HASIJA, 1992. Relative contributionc of bacteria and fungi to water hyacinth decompocition. Aquat. Bot., 43: 1-15.

GESSNER, M.O., 1991. Differences in processing dynamics of fresh and dried ieaf iitter in a stream ecosytem. Freshwat. Biol., 26: 387-398.

GESSNER, M.O. \& M. DOBSON, 1993. Colonisation of fresh and dried leaf litter by lotic invertebrates. Arch. Hydrobiol., 127: 141-149.

GESSNER, M.O. \& J. SCHWOERBEL, 1989. Leaching kinetics of fresh ieaf-iitter with implications for the current concept of leaf-processing in streams. Arch. Hydrobiol., 115: 81-90.

GESSNER, M.O., M. THOMAS, A.-M. JEAN-LOUIS \& E. CHAUVET, 1993. Stable successionai patterns of aquatic hyphomycetes on leaves decaying in a summer cool stream. Mycol. Res., 97: 163-172.

GESSNER, M.O., K. SUBERKROPP \& E. CHAUVET, 1997. Decomposition of piant litter in marine and freshwater ecosystems. In: The Mycota (G.C. WICKLOW \& B.E. SODERSTROM, eds.): 303-322. Springer-Verlag, Berlin.

GESSNER, R.V. \& R.D. GOOS, 1973. Fungi from decomposing Spartina alterniflora. Can.J. Bot, 51:51-55.

GODSHALK, G.L. \& R.G. WETZEL. 1978 a. Decomposition of aquatic angiosperms. I. Disolved components. Aquat. Bot., 5: 281-300.
GODSHALK, G.L. \& R.G. WETZEL, 1978 b. Decomposition of aquatic angiosperms. II. Particulate components. Aquat. Bot.. 5: 301-327.

GODSHALK, G.L. \& R.G. WETZEL, 1978 c. Decomposition of aquatic angiosperms. III. Zostera marina $\mathrm{L}$. and a conceptual model of decomposition. Aquat. Bot., 5: 329 354.

GRUBBS. S.A. \& K.W. CUMMINS, 1994. A leaf-toughness method for directly measuring the processing of naturally entrained leaf detritus in streams. J. N. Am. Benthol. Soc., 13: 68-73.

HANLON. D.G., 1982. The breakdown and decomposition of ailochthonous and aiitochthonous piant iitter in an oligotrophic lake (Llyn Frongoch). Hydrobiologia, 88: 281-288.

HASLAM, S.M., 1978. River plants. Cambridge University Presc, Cambridge.

HEDGER, J., 1990. Fungi in the tropical forest canopy. Mycologist, 4: 200-202.

HYNES, H.B.N., 1970. The ecology of running waters. University of Toronto Press, Toronto.

IKUSIMA, I. \& J.G. GENTIL, 1996. Evaluation of the faster initial decomposition of tropical floating ieaves of Nymphaea elegans Hook. Ecol. Res., 11 : 201-206.

INGOLD, C.T., 1955. Aquatic ascomycetes: further species from the Engiish Lake District. Trans. Br. Mycol. Soc., 38: 157 168.

JOHNSON. D.A., L.M. CARRIS \& J.D. ROGERS, 1997. Morphoiogical and molecular characterization of Colletotrichum nymphaeae and C. nupharicola sp. nov. on water-lilies (Nymphaea and Nuphar). Mycol. Res., 101: 641649.

KAUSHIK, N.K. \& H.B.N. HYNES, 1971. The fate of the dead leaves that fall into streams. Arch. Hydrobiol., 68: 465515.

KOHLMEYER, J. \& E. KOHLMEYER, 1979. Marine mycology. Academic Press, New York.

KOK, C.J. \& G. VAN DER VELDE, 1994. Decomposition and macroinvertebrate coionization of aquatic and terrestriai leaf material in alkaline and acid still water. Freshwat. Biol., 31: 65-75.

KOK, C.J., W. HAVERKAMP \& H.A. VAN DER AA, 1992. Influence of $\mathrm{pH}$ on the growth and leaf-macerating ability of fungi involved in the decomposition of floating leaves of Nymphaea alba in an acid water. J. Gen. Microbiol.. 138: 103108.

KOK, C.J., H.W.G. MEESTERS \& A.J. KEMPERS, 1990. Decoinposition rate, chemicai composition and nutrient recycling of Nymphaea alba L. floating leaf biade detritus as 
influenced by $\mathrm{pH}$, alkalinity and aluminium in laboratory experiments. Aquat. Bot., 37: 215-227.

KORNIJÓW, R., R.D. GULATI \& T. OZIMEK, 1995. Food preference of freshwater invertebrates: comparing fresh and decomposed angiosperm and a filamentous alga. Freshwat. Biol., 33: 205-212.

KUEHN, K.A., 1997. Standing dead decomposition of the freshwater emergent macrophyte Juncus effusus L. Ph. D. Thesis, University of Alabama, Tuscaloosa.

LARSEN, V. J., 1982. The effects of pre-drying and fragmentation on the leaching of nutrient elements and organic matter from Phragmites australis (Cav.) Trin. litter. Aquat. Bot., 14: 29-39.

LOCK, M.A., 1993. Attached microbial communities in rivers. In: Aquatic microbiology. (T.A. FORD, ed.): 113-138. Blackwell, Oxford.

LODGE, D.J. \& C.E. ASBURY, 1988. Basidiomycetes reduce export of organic matter from forest slopes. Mycologia, 80: 888-890.

LUNT, H.A., 1933. Effects of weathering upon composition of hardwood leaves. J. Forest., 31:43-45.

MANN, K.H., 1982. Ecology of coastal water. University of California Press, Berkeley \& Los Angeles.

MASON, C.F., 1976. Relative importance of fungi and bacteria in the decomposition of Phragmites leaves. Hydrobiologia, 5 1: 65-69.

MASON, C.F. \& R.J. BRYANT, 1975. Production, nutrient content and decomposition of Phragmites communis Trin. and Typha angustifolia L. J. Ecol., 63:71-95.

MATILE, P. 1986. Blattseneszenz. Biol. Rundsch., 24: 34965.

MORAN, M.A., T. LEGOVIC, R. BENNER \& R.E. HODSON, 1988. Carbon flow from lignocellulose: a simulation analysis of a detritus-based ecosystem. Ecology, 69: 1525-1536.

MORRIS, J.T. \& K. LAJTHA, 1986. Decomposition and nutrient dynamics of litter from four species of freshwater emergent macrophytes. Hydrobiologia, 131 : 215-223.

NEWELL, S.Y., 1993. Decomposition of shoots of a saltmarsh grass. Methodology and dynamics of microbial assemblages. Adv. Microb. Ecol., 13:301-326.

NEWELL, S.Y. \& R.D. FALLON, 1989. Litterbags, leaf tags, and decay of nonabscised intertidal leaves. Can. J. Bot., 67: 2324-2327.

NEWELL, S.Y., J.D. MILLER \& R.D. FALLON, 1989. Decomposition and microbial dynamics for standing, naturally positioned leaves of the salt-marsh grass Spartina alterniflora. Mar: Biol., 101:471-481.

NEWELL, S.Y., M.A. MORAN, R. WICKS \& R.E. HOD-
SON, 1995. Productivities of microbial consumers during early stages of decomposition of leaves of a freshwater sedge. Freshwat. Biol., 34: 135-148.

NEWMAN, R.M. 1990. Effects of shredding amphipod density on watercress Nasturtium officinale breakdown. Holarct. Ecol, 13: 293-299.

NEWMAN, R.M., 1991. Herbivory and detritivory on freshwater macrophytes by invertebrates: a review. J. N. Am. Benthol. Soc., 10:89-114.

NYKVIST, N., 1963. Leaching and decomposition of watersoluble organic substances from different types of leaf and needle litter. Stud. Forest. Suec, 3: 3-31.

OLÁH, J., 1972. Leaching, colonization and stabilization during detritus formation. Mem. Ist. Ital. Idrobiol.. 29: 105-127.

POLUNIN, N.V.C., 1984. The decomposition of emergent macrophytes in fresh water. Adv. Ecol. Res., 14:115-166.

POZO, J. \& R. COLINO, 1992. Decomposition processes of Spartina maritima in a salt marsh of the Basque Country. Hydrobiologia, 231: 165-175.

PUGH, G.J.F. \& J.L. MULDER, 1971. Mycoflora associated with Typha latijolia. Trans. Br. Mycol. Soc., 57: 273-282.

REICE, S.R. 1974. Environmental patchiness and the breakdown of leaf litter in a woodland stream. Ecology, 55: 1271 1282.

ROGERS, K.H. \& C.M. BREEN, 1982. Decomposition of Potamogeton crispus L.: the effects of drying on the pattern of mass and nutrient loss. Aquat. Bot., 12:1-12.

ROUNICK, J.S. \& M.J. WINTERBOURN, 1983. The formation, structure and utilization of stone surface layers in two New Zealand streams. Freshwat. Biol., 13, 57-72.

SAMIAJI, J. \& F. BARLOCHER, 1996. Geratology and decomposition of Spartina alterniflora Loisel in a New Brunswick saltmarsh. J. Exp. Mar. Biol. Ecol., 201 :233-252.

SRIDHAR, K.R. \& E BARLOCHER, 1993. Seasonal changes in microbial colonization of fresh and dried leaves. Arch. Hydrobiol., 128: 1-12.

SRIDHAR, K.R., K.R. CHANDRASHEKHAR \& K.M. KAVERIAPPA, 1992. Research on the Indian subcontinent. In: The ecology of aquatic hyphomycetes. (F. BARLOCHER, ed.). 182-211. Springer-Verlag, Berlin.

STOUT, R.J., W.H. TAFT \& R.W. MERRIT, 1985. Patterns of macroinvertebrate colonization on fresh and senescent alder leaves in two Michigan streams. Freshwat. Biol., 15:573-580.

SUBERKROPP, K., G.L. GODSHALK \& M.J. KLUG, 1976. Changes in the chemical composition of leaves during processing in a woodland stream. Ecology, 57: 720-727.

TALIGOOLA, T.K., A.E. APINIS \& C.G.C. CHESTERS, 1972. Microfungi colonizing collapsed aerial parts of 
Phragmites communis Trin. in water. Nova Hedwigia, 23: 465472.

TAYLOR, B.R. \& F. BARLOCHER, 1996. Variable effects oí air-drying on leaching losses from tree leaf litter. Hydrohiologia, 325: 173-182.

TEAL. J.M. 1962. Energy flow in the salt marsh ecosystem of Georgia. Ecology, 43: 614-624.

THOMPSON, J.E., C.D. FROESE, Y. HONG, K.A. HUDAK \& M.D. SMITH, 1997. Membrane deterioration during senescence. Can. J. Bot., 75: 867-879.

THURMAN, E.A. 1985. Organic geochemistry of natural waters. Nijhoff/Junk, Dordrecht.
WEBSTER. J., S.T. MORAN \& R.A.DAVEY, 1976. Growth and sporulation oí Tricladium chaetocladium and Lunulospora curvula in relation to temperature. Trans. Br. mycol. Soc.. 67: 491-495.

WEBSTER. J.R.\& E.F. BENFIELD, 1086. Vascular plant brcakdown in freshwater ecosystems. Ann. Rev. Ecol. Syst., 17: 567-594.

WESTLAKE. D.F., 1963. Comparison of plant productivity. Biol. Rev., 38: 385-425.

WETZEL, R.G., 1983. Limnology. Saunders, Philadelphia.

WETZEL, R.G.. 1990. Land-water interfaces: metabolic and limnological regulators. Verh. int. Ver. Limnol.. 24: 6-24. 
